\title{
A NOVEL PERFORMANCE EVALUATION FRAMEWORK FOR NEW SERVICE DEVELOPMENT IN THE HEALTHCARE INDUSTRY USING HYBRID ISM AND ANP
}

\author{
Jalil HEIDARY DAHOOIE ${ }^{(1)}$, Navid MOHAMMADI(1) \\ Ieva MEIDUTĖ-KAVALIAUSKIENĖ ${ }^{2 *}$ Arūnė BINKYTĖ-VELIENE ${ }^{3}$ \\ ${ }^{1}$ Faculty of Management, University of Tehran, Tehran, Iran \\ ${ }^{2}$ Faculty of Business Management, Vilnius Gediminas Technical University, Vilnius, Lithuania \\ ${ }^{3}$ Laboratory of Smart Building Systems, Institute of Sustainable Construction, Vilnius Gediminas \\ Technical University, Vilnius, Lithuania
}

Received 09 October 2020; accepted 16 May 2021

\begin{abstract}
Today, the innovative activities of companies in new service development (NSD) have an undeniable contribution to the economic development of countries. Given the recent advances in the healthcare industry, the issue of NSD and performance management of firms operating in this industry has received special attention of researchers and decision makers. A review of previous research shows that on the one hand there is no agreement among experts on NSD performance measurement criteria and on the other hand there has been no systematic framework that can measure and manage firm performance in this area. The proposed framework should allow for interaction between different decision makers, considering multiple and sometimes conflicting criteria. In this regard, this paper aimed to provide a framework to assess the NSD performance in healthcare industry using multiple-criteria-decision-making methods. The proposed model consists of 17 different criteria that have been identified and finalized based on previous studies as well as experts' opinions. Then, the indicators are classified with the help of experts in the form of a balanced scorecard model and presented as an initial model. Due to internal relationships between criteria, this model was evaluated using interpretive structural modelling and modelled at 5 different levels. Then, the analytic network process approach was applied to determine criteria weights. Finally, new service development performance in Moheb hospital was evaluated through the framework proposed here.
\end{abstract}

Keywords: new service development, performance evaluation, ANP, ISM, healthcare industry.

JEL Classification: M00, M19, O30.

${ }^{\star}$ Corresponding author. E-mail: ieva.meidute-kavaliauskiene@vilniustech.lt

Copyright (C) 2021 The Author(s). Published by Vilnius Gediminas Technical University

This is an Open Access article distributed under the terms of the Creative Commons Attribution License (http://creativecommons. org/licenses/by/4.0/), which permits unrestricted use, distribution, and reproduction in any medium, provided the original author and source are credited. 


\section{Introduction}

In today's competitive global business world, services constitute a major part of total economic activity and employment in most economies (De Jong \& Vermeulen, 2003). Therefore, the field of services has been introduced as one of the vital components of economic development and one of the most important drivers of sustainable development in countries (especially developed countries) (Ghani \& O’Connel, 2014; Wamboye \& Nyaronga, 2018). Due to this key role, today the development of services has not only been considered by researchers in this area, but also by policy makers and planners at different levels (organization, industry and country).

The companies have found that their survival and continuity are linked to innovations in the development of new products and/or services that lead to increased number of customers and more satisfaction (Cowell, 1988; Kim \& Meiren, 2010; Yeh et al., 2019).

The share of the healthcare industry, and in particular the hospital services sector, in the service-related economy is growing rapidly (Behdioğlu et al., 2019). The development of information technology has played a major role in the development of health services (Chan \& Kaufman, 2010). The impact of these technologies has been so significant that by 2013, more than 1,500 new services in this field have been introduced to the market (Fiordelli et al., 2013). It can be boldly claimed that the healthcare industry in general is one of the most important areas for the development of new services and will have a significant impact on economic development, social welfare and job creation. These innovations have been used in various fields in the medical industry of countries, including innovation in service delivery, innovation in products, innovation in internal processes of hospitals, improving the quality of services and products, and the use of ideation platforms in hospitals. These innovations will have positive effects on the patients' well-being, the quality of hospitals, the effectiveness of the insurance industry, as well as the economic development and social welfare (Elg et al., 2012; Kriegel et al., 2013).

Along with the significant growth of services in the 21 st century and globalization, the need to measure the performance, quality of service delivery, as well as their value position has even felt more (Tseng et al., 2015). Results obtained from effective performance evaluation are very important and make significant contributions to the growth, development and competitiveness in a wide range of industries (Mikolajczyk \& Schmid, 2005; Lai \& Yuen, 2019; Letina et al., 2020). In particular, in the field of the development or new services/ products, the discussion of performance evaluation has been of great interest, and there are many different definitions and perspectives on its research focus.

However, through a review on the literature, we can find that researchers have put more focus on the investigation of new product development (NPD). Also, as the evidence suggested, a variety of frameworks and models have been presented to assess the performance of the NPD process. However, there is no in-depth review for a new service development and only some studies only addressed factors affecting the service development process and its success (Shyu et al., 2012). On the other hand, previous researches in NSD area, focused on some industries such as hospitality and banking (Victorino et al., 2005; Tseng et al., 2015), while the healthcare industry has been under considered in the researches despite being one of the largest and fastest-growing industries in the world (Major, 2019; Lee et al., 2011). 
Various reasons including great pressure to reduce service costs, competition for delivery of high quality, efforts to obtain certificates and governmental licenses, establishing a valid and reliable service brand and cooperation with other enterprises make it clear that there is a need for new service development in this industry (Price Waterhouse Cooper [PWC], 2014).

Examining the research literature reveals that many different criteria have been proposed by several researchers for the performance evaluation of new service development.

Due to the lack of agreement on these criteria and also the lack of a systematic process to manage the performance of healthcare industry organisations, the present study has tried to provide a framework to identify criteria appropriate to this industry and enable firms to measure performance so that their decision makers can better manage NSD-related issues.

Regarding insights provided by scholars and thinkers in this field, we can find out that there are a variety of financial and non-financial factors influencing performance evaluation of the development of a new service/product, which should be considered within the context of accurate assessment. The balanced score card (BSC) is a good technique that can be used to integrate different criteria. This model was developed by Kaplan and Norton as a performance evaluation framework with four perspectives (Kaplan \& Norton, 2005; Sartor, 2019): Financial, Customer, Internal Process, and Learning and Growth, with an acceptable coverage of individual criteria to evaluate new service/product development activities.

Considering the mentioned characteristics, four areas addressed in the balanced scorecard approach were considered to classify the identified criteria. On the other hand, some factors have made performance measurement a multi-criteria-decision-making (MCDM) problem including the multiplicity of criteria, which are sometimes conflicting and independent, along with the multiplicity of decision makers who each have different priorities. Accordingly, a combination of interpretive structural modeling (ISM) and analytical network process (ANP) has been proposed in order to form the desired framework. The ISM method allows the modeling of the relationship between the identified indicators. The ANP approach has been used to calculate the weights and the importance of the identified criteria by considering the extracted relationships. In order to show the feasibility of the proposed framework in the real world, this model has been applied to measure the performance of Moheb Hospital in the field of NSD.

In the first part of this article, the literature related to the development of new services has been reviewed and the related evaluation criteria have been extracted from the context of literature. In the next section, the research method and analysis of the findings are presented. In the fourth section, data analysis is presented and after explaining the case study, the data analysis process is fully described using two methods of ISM and ANP. In the discussion section, the results of the performed analyzes are provided, and finally in the last section, the conclusions and suggestions for future research are presented.

\section{Literature review}

NSD refers to a key strategic factor in creating value to enhance the profitability of existing customers and motivate prospects. This process involves a variety of practices, starting with the formulation of new service targets, followed by designing services and delivery and, ultimately engaged in a full-scale implementation (Busagara et al., 2020; Kitsios \& Kamariotou, 
2020). In NSD, the term "new" is fuzzy in nature (Fitzsimmons \& Fitzsimmons, 2006). From this perspective, new services require a new innovation; an item that has never existed. To put it on a more comprehensive definition, NSD deals with gradual innovations which include past services with some degrees (Fitzsimmons \& Fitzsimmons, 2006; Kitsios \& Kamariotou, 2020; Lima \& Teixeira, 2020; Liu et al., 2020). The growing pace of world-level services has led to an increased need to improve services performance and provide a higher quality. Obviously, the availability of a more accurate and comprehensive framework for assessing the NSD performance seems inevitable. Therefore, this study aims to provide a performance evaluation framework for new service development in the healthcare industry.

A review of previous research presented in Table 1 shows that although several articles have been published in the field of evaluating the performance of the new product development (NPD) process, the issue of NSD performance has not received much attention and only some articles with different goals (such as statistical analysis) have addressed some criteria and indicators.

As discussed in the Table 1, a large amount of previous research have been only focused on the evaluation and modelling of statistical relationships between criteria. Also, Examination of the above criteria shows that there is no agreement between researchers on the criteria for measuring NSD performance and therefore classifying the criteria in the form of an accepted approach such as a balanced scorecard can increase the acceptability of the proposed model. The BSC framework covers all the dimensions required for evaluation and has also been used in the studies reviewed in the literature (Dinçer \& Yüksel, 2018).

On the other hand, a review of articles shows that researchers have been less likely to look for a model to measure and compare firm performance in the field of new service development; however, assessing the current situation allows for better management in this area. It is necessary to simultaneously pay attention to various criteria which are sometimes conflicting and have different importance from the perspective of different decision makers. In some cases, these criteria are also independent, some of which are qualitative and based on expert opinions. Hence, MCDM methods have been used in the areas such as NPD (Ying et al., 2018; Goswami et al., 2021). Due to the need to pay attention to the relationship between these criteria, approaches used in this area should consider interactions between the criteria in the process of determining the importance. The ANP method was introduced as one of the most well-known methods in this category by Saati (1996) and has been used in numerous studies. One of the main problems of this method is to determine the communication network between the criteria (Gölcük \& Baykasoğlu, 2016) and for this reason, in this article, the ISM method has been used to form this network.

\section{Methodology}

This research aims to provide a framework for assessing the NSD performance in the healthcare industry. To this end, the research procedures are carried out in four main steps. First, through a review of the theoretical and empirical research studies, the performance evaluation criteria of the new service development are derived from the literature. 
Table 1. Literature review (methods and criteria)

\begin{tabular}{|c|c|c|}
\hline References & Methodology & Criteria \\
\hline $\begin{array}{l}\text { (Cheng \& } \\
\text { Krumwiede, } \\
\text { 2012) }\end{array}$ & $\begin{array}{l}\text { Statistical } \\
\text { method } \\
\text { (Mean, SD, } \\
\text { etc.) }\end{array}$ & $\begin{array}{l}\text { - business profit } \\
\text { - market share } \\
\text { - return on investment } \\
\text { - customer satisfaction } \\
\text { - customer loyalty } \\
\text { - brand equity value }\end{array}$ \\
\hline $\begin{array}{l}\text { (Storey \& Kelly, } \\
\text { 2001) }\end{array}$ & $\begin{array}{l}\text { Statistical } \\
\text { method }\end{array}$ & $\begin{array}{l}\text { A list of } 15 \text { criteria for performance evaluation of a new service } \\
\text { development, including } \\
\text { - profit } \\
\text { - sales } \\
\text { - revenue } \\
\text { - customer satisfaction } \\
\text { - And so on. }\end{array}$ \\
\hline (Lee et al., 2010) & $\begin{array}{l}\text { analytic } \\
\text { network } \\
\text { process (ANP) }\end{array}$ & $\begin{array}{l}\text { - Cost } \\
\text { - potential turnover } \\
\text { - likely profit } \\
\text { - cost benefit analysis } \\
\text { - revenue impact } \\
\text { - Market benefits } \\
\text { - client needs } \\
\text { - global market needs } \\
\text { - match competition } \\
\text { - And so on. }\end{array}$ \\
\hline $\begin{array}{l}\text { (Blindenbach- } \\
\text { Driessen et al., } \\
2010)\end{array}$ & $\begin{array}{l}\text { Statistical } \\
\text { method }\end{array}$ & $\begin{array}{l}\text { - Adherence to Schedule } \\
\text { - Adherence to Budget } \\
\text { - Quality } \\
\text { - Captured Knowledge } \\
\text { - Adhering to Project Goals } \\
\text { - Overall Satisfaction } \\
\text { - Met Profit Goals } \\
\text { - Met Revenue Goals } \\
\text { - And so on. }\end{array}$ \\
\hline $\begin{array}{l}\text { (Bendoly et al., } \\
\text { 2012) }\end{array}$ & $\begin{array}{l}\text { Statistical } \\
\text { method } \\
\text { (Regression) }\end{array}$ & $\begin{array}{l}\text { - coordinating marketing- production processes } \\
\text { - supply chain coordination } \\
\text { - information system capability } \\
\text { - supply chain intelligence } \\
\text { - market intelligence } \\
\text { - market dynamisms }\end{array}$ \\
\hline $\begin{array}{l}\text { (Melton \& } \\
\text { Hartline, 2013) }\end{array}$ & $\begin{array}{l}\text { Statistical } \\
\text { method }\end{array}$ & $\begin{array}{l}\text { - sales } \\
\text { - market share } \\
\text { - profit margin } \\
\text { - impact on other product sales } \\
\text { - applicability } \\
\text { - costs } \\
\text { - reduced lag time from conceptualization to implementation } \\
\text { - Reduced lag time from building prototype to implementation. }\end{array}$ \\
\hline $\begin{array}{l}\text { (Menor \& Roth, } \\
\text { 2007) }\end{array}$ & $\begin{array}{l}\text { Statistical } \\
\text { method (path } \\
\text { loadings, } \\
\text { Correlation) }\end{array}$ & $\begin{array}{l}\text { - NSD process focus } \\
\text { - Market acuity } \\
\text { - NSD strategy } \\
\text { - NSD culture } \\
\text { - IT experience } \\
\text { - NSD program performance }\end{array}$ \\
\hline
\end{tabular}


End of Table 1

\begin{tabular}{|c|c|c|}
\hline References & Methodology & Criteria \\
\hline $\begin{array}{l}\text { (Menor \& Roth, } \\
\text { 2008) }\end{array}$ & $\begin{array}{l}\text { Statistical } \\
\text { method } \\
\text { (Mean, S D, } \\
\text { Skewness, } \\
\text { Kurtosis) }\end{array}$ & $\begin{array}{l}\text { - NSD process focus } \\
\text { - Market acuity } \\
\text { - NSD strategy } \\
\text { - NSD culture } \\
\text { - IT experience } \\
\text { - NSD program performance } \\
\text { Each category consists of four sub-criteria, so a total of } 28 \text { sub- } \\
\text { criteria were defined for the performance evaluation }\end{array}$ \\
\hline $\begin{array}{l}\text { (Melton \& } \\
\text { Hartline, 2010) }\end{array}$ & $\begin{array}{l}\text { Statistical } \\
\text { method } \\
\text { (Factor } \\
\text { Analysis, } \\
\text { t-Value) }\end{array}$ & $\begin{array}{l}\text { Two categories of sales performance and effective } \\
\text { implementation and six sub-criteria, including: } \\
\text { - Sales } \\
\text { - market share } \\
\text { - profit margin } \\
\text { - reduction in costs } \\
\text { - reduced lag time in design } \\
\text { - decreased lag time in service delivery }\end{array}$ \\
\hline $\begin{array}{l}\text { (Storey \& } \\
\text { Hughes, 2013) }\end{array}$ & $\begin{array}{l}\text { Statistical } \\
\text { method } \\
\text { (Correlation, } \\
\text { Regression) }\end{array}$ & $\begin{array}{l}\text { - NSD capability } \\
\text { - Learning culture } \\
\text { - Entrepreneurial culture } \\
\text { - Strategic orientation } \\
\text { - Controls } \\
\text { - numbers of new service, and success rate of projects } \\
\text { - firm size }\end{array}$ \\
\hline $\begin{array}{l}\text { (Weng \& } \\
\text { Huang, 2012) }\end{array}$ & $\begin{array}{l}\text { Factor analysis } \\
\text { by AMOS } 5.0\end{array}$ & $\begin{array}{l}\text { - ability to integrate customer knowledge } \\
\text { - ability to capture knowledge by customers } \\
\text { - customer communication capabilities } \\
\text { - the ability to create knowledge by customers }\end{array}$ \\
\hline $\begin{array}{l}\text { (Jiménez-Zarco } \\
\text { et al., 2011) }\end{array}$ & $\begin{array}{l}\text { Statistical } \\
\text { method } \\
\text { (Mean, S D, } \\
\text { ANOVA, } \\
\text { Coefficient) }\end{array}$ & $\begin{array}{l}\text { - Client and marketing fit } \\
\text { - Equipment-based service } \\
\text { - Market competitiveness } \\
\text { - Service newness to firm } \\
\text { - Service expertise } \\
\text { - Service customization } \\
\text { - Service superiority/innovativeness } \\
\text { - Formal NSD process } \\
\text { - Respond to demand cycle } \\
\text { - Satisfied with current service } \\
\text { - Effective NSD culture } \\
\text { - Long-term client relationships } \\
\text { - Market size } \\
\text { - Customer participation } \\
\text { - Service process uniformity }\end{array}$ \\
\hline $\begin{array}{l}\text { (Kriegel et al., } \\
\text { 2013) }\end{array}$ & $\begin{array}{l}\text { Statistical } \\
\text { methods }\end{array}$ & $\begin{array}{l}\text { - Product } \\
\text { - Price } \\
\text { - Process } \\
\text { - People }\end{array}$ \\
\hline
\end{tabular}


Then, with the aim of creating a suitable model for measuring NSD performance, experts were asked to categorize these criteria in the form of four common aspects of the BSC approach. In order to localize the criteria and coordinate them with the characteristics of the healthcare industry, these criteria were provided to members of the panel of industry experts. The panel consisted of health industry managers who, on the one hand, had more than 15 years of work experience in the hospital and, on the other hand, were familiar with the concepts of new product and service development through academic education in fields such as entrepreneurship and technology management.

As the finalized criteria are related to each other, changes in a given criteria and improvements of its status can lead to changes in others. To put it differently, the criteria used to evaluate the performance of new service development are related to each other and the assessment of degrees of driving power and dependency of every criteria is required. Now, due to the multiplicity of criteria, ISM is used in this study to accurately identify these relationships and to distinguish effective criteria from affecting criteria

Due to the need to assess the relationships between final evaluation criteria and to design the evaluation model, an interpretive structural modelling analysis is used to specify the performance evaluation model and to determine their relationships. Since, different criteria do not have similar and equal effect on successful performance, so the third stage deals with weighting each criterion.

To measure relationships between the criteria using the ISM approach, a group consisting of ten experts and specialist managers are chosen from hospitals of Tehran. Interviews are used for data collection to propose an interpretive structural model. In this case, each expert is interviewed and the relationship matrix for criteria is developed accordingly. The experts are selected using the snowball sampling from experienced senior managers in the field of hospital service development. Interviews took approximately 2-3 hours. As the relationship matrix developed, the experts' opinions are to be aggregated as a matrix. For this regard, relations with agreement scores of higher than the average are confirmed, while those with the degree of lower-than-average agreement are rejected. Then, using the Boolean algebra, the final matrix is proposed to obtain the ISM model. Because of interrelationships between the criteria and their interdependence, the analytical network process (ANP) is applied to calculate criteria weights. This process is carried out by using the Super Decision software, with the participation of the selected panel of experts. To this end, the relationships obtained in the ISM technique are implemented in a hierarchical analysis process in order to be evaluated by the experts, so the final weight of all criteria are determined. In this stage, three experts are chosen by general consensus among experts that engaged in ISM matrix developing stage to achieve the best and most accurate opinions on the importance of criteria. The arithmetic mean of expert opinions is determined and aggregated. At the fourth step, the NSD performance at Moheb Hospital is measured as a case study using the framework proposed here. This hospital is selected as the case study because of its experience in new services development. Since its founding, it has been operating towards service development which has been defined as an organizational strategy. Long-term experiences of the hospital in providing new services and also the need to assess the outcomes of its new development service process are other reasons to select this case. The reports, documents and expert opinions are collected from all people involved in the process of new service development in this Hospital. 


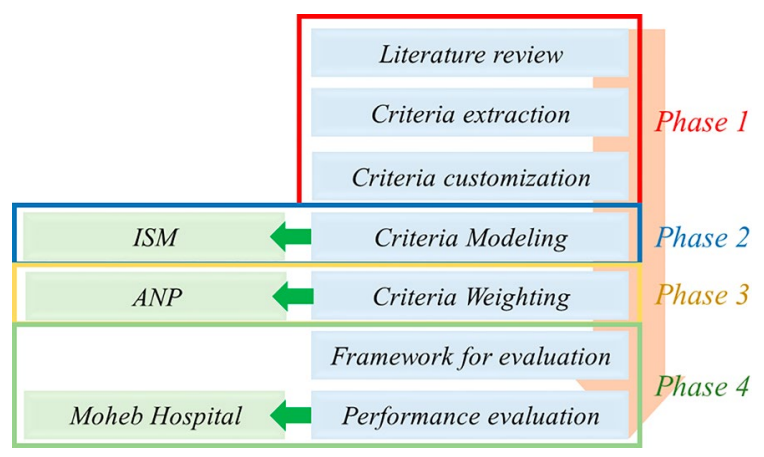

Figure 1. Research procedures

Several periodic meetings were held with people directly engaged in the process of new service development called the Moheb Thought Room. In the meetings, the service development process is followed from Idea generation to service lunch and each person has explicit specialization with particular steps of that process. This study takes benefits from opinions of all participators and documentation from internal assessments of the hospital. The research procedures are summarized in Figure 1.

\section{Data analysis}

However, the main objective of this paper is to evaluate outcomes of the new service development process after a three to five-year timeline in a given hospital/health centre. To this end, Moheb Hospital is selected as the case study and the performance results obtained from a three-year period time are evaluated for the development of new services.

Moheb is the name of a hospital in Iran that has good experience in developing services and products. Some of the important practices of this hospital in order to develop new services are summarized below:

- Designing a think tank to develop new services;

- Providing an ideation platform for service development among employees;

- Providing a Customer Relationship Platform to review comments, suggestions and criticisms regarding new hospital services;

- Providing insurance services online or with self-service devices;

- Providing imaging services for children in a childish and gamification atmosphere;

- Providing entertainment services for inpatients;

- Providing remote services and online booking of doctor's appointment;

- Providing test results and their analysis online.

According to the first stage of the research procedure already described, the criteria for performance evaluation of new service development are extracted through the literature review. Then, using the opinions of experts in the field of hospital service development, the selected criteria are finalized and categorized as the balanced scorecard model. These criteria are shown in Table 2. 
Table 2. List of final criteria

\begin{tabular}{|c|c|c|c|c|c|}
\hline No. & Criteria & Code & Sub-criteria & definition & References \\
\hline \multirow{6}{*}{1} & \multirow{6}{*}{ Financial } & $\mathrm{C} 1$ & $\begin{array}{l}\text { Sales }{ }^{1} \text { and } \\
\text { new service } \\
\text { delivery }\end{array}$ & $\begin{array}{l}\text { How much has been the hos- } \\
\text { pital's new services delivery } \\
\text { rate over the past three years? }\end{array}$ & $\begin{array}{l}\text { (Kriegel et al., 2013; Storey } \\
\text { \& Hughes, 2013; Kitsios \& } \\
\text { Grigoroudis, 2020) }\end{array}$ \\
\hline & & $\mathrm{C} 2$ & $\begin{array}{l}\text { Profit (from } \\
\text { new services) }\end{array}$ & $\begin{array}{l}\text { How much has been the hos- } \\
\text { pital's profit from new service } \\
\text { deliveries over the past three } \\
\text { years? }\end{array}$ & $\begin{array}{l}\text { (Blindenbach-Driessen et al., } \\
\text { 2010; Cheng \& Krumwiede, } \\
\text { 2012; Lee et al., 2010; } \\
\text { Melton \& Hartline, 2010; } \\
\text { Menor \& Roth, 2008; Storey } \\
\text { \& Kelly, 2001; Lin \& Hsieh, } \\
\text { 2011; Dinçer \& Yüksel, } \\
\text { 2018) }\end{array}$ \\
\hline & & $\mathrm{C} 3$ & $\begin{array}{l}\text { Market share } \\
\text { (increased in } \\
\text { exchange for } \\
\text { new services) }\end{array}$ & $\begin{array}{l}\text { How much the new services } \\
\text { increased the hospital mar- } \\
\text { ket share over the past three } \\
\text { years? }\end{array}$ & $\begin{array}{l}\text { (Blindenbach-Driessen et al., } \\
\text { 2010; Cheng \& Krumwiede, } \\
\text { 2012; Melton \& Hartline, } \\
\text { 2010, 2013; Storey \& Kelly, } \\
\text { 2001; Tseng et al., 2015) }\end{array}$ \\
\hline & & $\mathrm{C} 4$ & $\begin{array}{l}\text { Revenues } \\
\text { from new } \\
\text { service }\end{array}$ & $\begin{array}{l}\text { How much has been the hos- } \\
\text { pital's revenues from new ser- } \\
\text { vice deliveries over the past } \\
\text { three years? }\end{array}$ & $\begin{array}{l}\text { (Bendoly et al., 2012; } \\
\text { Blindenbach-Driessen et al., } \\
\text { 2010) }\end{array}$ \\
\hline & & $\mathrm{C} 5$ & $\begin{array}{l}\text { Return on } \\
\text { investment } \\
\text { (from new } \\
\text { services) }\end{array}$ & $\begin{array}{l}\text { How much has been the hos- } \\
\text { pital's return on investment } \\
\text { from new service deliveries } \\
\text { over the past three years? }\end{array}$ & (Storey \& Kelly, 2001) \\
\hline & & C6 & $\begin{array}{l}\text { Implementa- } \\
\text { tion costs } \\
\text { (new Service) }\end{array}$ & $\begin{array}{l}\text { How much has been the } \\
\text { Implementation costs of the } \\
\text { hospital's new services over } \\
\text { the past three years? }\end{array}$ & $\begin{array}{l}\text { (Storey \& Kelly, 2001; } \\
\text { Blindenbach-Driessen et al., } \\
\text { 2010; Lee et al., 2010; Cheng } \\
\text { \& Krumwiede, 2012; Wang } \\
\text { \& Tang, 2012) }\end{array}$ \\
\hline \multirow{5}{*}{2} & \multirow{5}{*}{ Customer } & C7 & \begin{tabular}{|l|} 
Customer \\
satisfaction \\
(from New \\
Services)
\end{tabular} & $\begin{array}{l}\text { How much the new services } \\
\text { increased the hospital's cus- } \\
\text { tomer satisfaction over the } \\
\text { past three years? }\end{array}$ & $\begin{array}{l}\text { (Storey \& Kelly, 2001; Menor } \\
\text { \& Roth, 2008; Blindenbach- } \\
\text { Driessen et al., 2010; Melton } \\
\text { \& Hartline, 2010) }\end{array}$ \\
\hline & & $\mathrm{C} 8$ & \begin{tabular}{|l|} 
Customer \\
loyalty (from \\
new services)
\end{tabular} & $\begin{array}{l}\text { How much the new services } \\
\text { increased the hospital's cus- } \\
\text { tomer loyalty over the past } \\
\text { three years? }\end{array}$ & (Cheng \& Krumwiede, 2012) \\
\hline & & C9 & $\begin{array}{l}\text { brand value } \\
\text { (from new } \\
\text { services) }\end{array}$ & $\begin{array}{l}\text { How much the new services } \\
\text { increased the hospital's brand } \\
\text { value over the past three } \\
\text { years? }\end{array}$ & $\begin{array}{l}\text { (Blindenbach-Driessen et al., } \\
\text { 2010; Cheng \& Krumwiede, } \\
\text { 2012; Dinçer \& Yüksel, } \\
\text { 2018) }\end{array}$ \\
\hline & & $\mathrm{C} 10$ & \begin{tabular}{|l|} 
New \\
customer \\
attraction \\
(from new \\
service) \\
\end{tabular} & $\begin{array}{l}\text { How much the new services } \\
\text { increased the rate of the hos- } \\
\text { pital's customer attraction } \\
\text { over the past three years? }\end{array}$ & (Storey \& Kelly, 2001) \\
\hline & & C16 & $\begin{array}{l}\text { General } \\
\text { service } \\
\text { status over } \\
\text { competitors }\end{array}$ & $\begin{array}{l}\text { How much the hospital gen- } \\
\text { eral service status has been } \\
\text { improved against the great- } \\
\text { est competitors (The greatest } \\
\text { competitor over the past three } \\
\text { years)? }\end{array}$ & (Menor \& Roth, 2008) \\
\hline
\end{tabular}


End of Table 2

\begin{tabular}{|c|c|c|c|c|c|}
\hline No. & Criteria & Code & Sub-criteria & definition & References \\
\hline \multirow{4}{*}{3} & \multirow{4}{*}{$\begin{array}{l}\text { Internal } \\
\text { Processes }\end{array}$} & C11 & $\begin{array}{l}\text { Reduced lag } \\
\text { time and ef- } \\
\text { fective imple- } \\
\text { mentation }\end{array}$ & $\begin{array}{l}\text { How much the hospital's } \\
\text { speed of new services imple- } \\
\text { mentation has been increased } \\
\text { in this period? }\end{array}$ & $\begin{array}{l}\text { (Storey \& Kelly, 2001; } \\
\text { Lee et al., 2010; Melton \& } \\
\text { Hartline, 2010; Cheng \& } \\
\text { Krumwiede, 2012; Shyu } \\
\text { et al., 2012; Wang \& Tang, } \\
\text { 2012; Dinçer \& Yüksel, } \\
\text { 2018) }\end{array}$ \\
\hline & & C12 & \begin{tabular}{|l|} 
Service \\
applicability \\
(new service \\
delivery) \\
\end{tabular} & $\begin{array}{l}\text { How much the hospital's new } \\
\text { services has been applicable } \\
\text { and practical over the past } \\
\text { three years? }\end{array}$ & (Menor \& Roth, 2008) \\
\hline & & C13 & $\begin{array}{l}\text { Quality } \\
\text { of service } \\
\text { (new service } \\
\text { delivery) }\end{array}$ & $\begin{array}{l}\text { How much the hospital's new } \\
\text { service quality has been im- } \\
\text { proved over the past three } \\
\text { years? }\end{array}$ & $\begin{array}{l}\text { (Blindenbach-Driessen et al., } \\
\text { 2010) }\end{array}$ \\
\hline & & C18 & $\begin{array}{l}\text { Speed of } \\
\text { service } \\
\text { development } \\
\text { against } \\
\text { competitors }\end{array}$ & $\begin{array}{l}\text { How much the hospital's new } \\
\text { service speed has been in- } \\
\text { creased against the competi- } \\
\text { tors over the past three years? }\end{array}$ & $\begin{array}{l}\text { (Menor \& Roth, 2008; } \\
\text { Cheng et al., 2020) }\end{array}$ \\
\hline \multirow{3}{*}{4} & \multirow{3}{*}{$\begin{array}{l}\text { Learning } \\
\text { and Growth }\end{array}$} & $\mathrm{C} 14$ & $\begin{array}{l}\text { Creating a } \\
\text { competitive } \\
\text { advantage }\end{array}$ & $\begin{array}{l}\text { How much the hospital's new } \\
\text { services has led to competi- } \\
\text { tive advantage over the past } \\
\text { three years? }\end{array}$ & $\begin{array}{l}\text { (Blindenbach-Driessen et al., } \\
\text { 2010) }\end{array}$ \\
\hline & & C15 & $\begin{array}{l}\text { Knowledge } \\
\text { gained from } \\
\text { new service } \\
\text { process }\end{array}$ & $\begin{array}{l}\text { How much has been the } \\
\text { Knowledge gained from new } \\
\text { service process over the past } \\
\text { three years? }\end{array}$ & $\begin{array}{l}\text { (Blindenbach-Driessen et al., } \\
\text { 2010; Tseng et al., 2015) }\end{array}$ \\
\hline & & C17 & $\begin{array}{l}\text { Percent of } \\
\text { successful } \\
\text { projects } \\
\text { (new service } \\
\text { projects) }\end{array}$ & $\begin{array}{l}\text { How much has been the } \\
\text { Percent of successful projects } \\
\text { over the past three years? }\end{array}$ & $\begin{array}{l}\text { (Menor \& Roth, 2008; Storey } \\
\text { \& Hughes, 2013; Storey \& } \\
\text { Kelly, 2001; Tseng et al., } \\
\text { 2015) }\end{array}$ \\
\hline
\end{tabular}

Note: ${ }^{1}$ Number of patient that use from new services such as new ultrasound machine.

As the final criteria are determined, this section describes the results obtained from the ISM, ANP, and provides the performance evaluation framework for new service development in the healthcare industry. Then, the performance of new service developments at Moheb Hospital is evaluated based on the model proposed here.

\subsection{Self-Interaction matrix from expert opinions}

After the experts were interviewed about new service developments in the healthcare industry, people with ability to provide accurate views on designing the performance evaluation framework for new service development were identified by using the Snowball sampling technique. This group included managers in different hospitals in Tehran city, and professional practitioners involved in the new service development activities. Through interviews with these experts in order to complete the self-interaction matrix from the criteria, their 
views were aggregated and the final self-interaction matrix of performance evaluation criteria was established (see Appendix for description of ISM methodology).

As collected via individual interviews, the opinions of experts are to be initially aggregated. To do this, expert matrices are evaluated and those relations with the degree of higher-than-average agreement are approved. However, relations with agreement scores of less than the average are rejected. Then, the areas under and over the matrix diameter are aggregated, presented as $\mathrm{X}, \mathrm{V}$ and $\mathrm{A}$ in Table 3. Table 3 illustrates the expert matrix for designing an interpretive structural modelling analysis.

For example, criteria 1 will affect on criteria 3, 7, 8, 10, 12, 13 and 14 (has been shown with A); and criteria 2, 4 and 5 will effect on criteria 1 (has been shown with V). Criteria 1 has no relationship with criteria $6,9,11,15,16,17$ and 18 (has been shown with O). Criteria 3 has two-sided relationship with criteria 9 and 10 (has been shown with X). According to these parameters (has been shown in Table 3), Table 4 has been obtained by binary numbers for extracting the ISM construction.

When the initial access matrix achieved, its internal consistency must be held. If Variable 1, for example, leads to Variable 2 and Variable 2 also leads to Variable 3, then Variable 1 have to lead to Variable 3. The lack of this relation requires to modify the matrix to replace missing relationships. To do this, the Boolean matrix multiplication is used. Table 5 shows the output of the Boolean multiplication access matrix. The matrix navigated the learned path five times to obtain a robust stability (Azar et al., 2010). For cells where 1 follows the star, it shows relationships that have been added after the matrix is matched.

Table 3. A structural self-interaction matrix to achieve internal relationships of variables

\begin{tabular}{|c|c|c|c|c|c|c|c|c|c|c|c|c|c|c|c|c|c|c|}
\hline & 1 & 2 & 3 & 4 & 5 & 6 & 7 & 8 & 9 & 10 & 11 & 12 & 13 & 14 & 15 & 16 & 17 & 18 \\
\hline 1 & & V & A & V & V & O & A & A & O & A & O & A & A & A & O & O & O & O \\
\hline 2 & & & A & A & V & A & O & A & O & O & O & O & O & O & O & O & A & O \\
\hline 3 & & & & O & O & O & A & A & X & X & O & O & A & V & O & A & O & O \\
\hline 4 & & & & & V & O & A & O & O & A & O & O & O & A & O & A & A & O \\
\hline 5 & & & & & & O & A & A & O & A & A & O & O & A & O & A & A & O \\
\hline 6 & & & & & & & O & O & O & O & O & O & O & A & O & A & O & O \\
\hline 7 & & & & & & & & V & V & V & A & A & A & V & O & O & O & O \\
\hline 8 & & & & & & & & & V & O & O & A & A & O & O & O & O & O \\
\hline 9 & & & & & & & & & & X & A & O & A & X & A & O & A & O \\
\hline 10 & & & & & & & & & & & O & A & A & A & O & A & O & A \\
\hline 11 & & & & & & & & & & & & O & O & V & A & V & O & X \\
\hline 12 & & & & & & & & & & & & & V & V & X & X & A & O \\
\hline 13 & & & & & & & & & & & & & & V & A & A & X & O \\
\hline 14 & & & & & & & & & & & & & & & O & A & A & A \\
\hline 15 & & & & & & & & & & & & & & & & X & X & V \\
\hline 16 & & & & & & & & & & & & & & & & & O & A \\
\hline 17 & & & & & & & & & & & & & & & & & O \\
\hline 18 & & & & & & & & & & & & & & & & & & \\
\hline
\end{tabular}


Table 4. A structural self-interaction matrix for ISM construction

\begin{tabular}{|c|c|c|c|c|c|c|c|c|c|c|c|c|c|c|c|c|c|c|}
\hline & 1 & 2 & 3 & 4 & 5 & 6 & 7 & 8 & 9 & 10 & 11 & 12 & 13 & 14 & 15 & 16 & 17 & 18 \\
\hline 1 & 1 & 1 & 0 & 1 & 1 & 0 & 0 & 0 & 0 & 0 & 0 & 0 & 0 & 0 & 0 & 0 & 0 & 0 \\
\hline 2 & 0 & 1 & 0 & 0 & 1 & 0 & 0 & 0 & 0 & 0 & 0 & 0 & 0 & 0 & 0 & 0 & 0 & 0 \\
\hline 3 & 1 & 1 & 1 & 0 & 0 & 0 & 0 & 0 & 1 & 1 & 0 & 0 & 0 & 1 & 0 & 0 & 0 & 0 \\
\hline 4 & 0 & 1 & 0 & 1 & 1 & 0 & 0 & 0 & 0 & 0 & 0 & 0 & 0 & 0 & 0 & 0 & 0 & 0 \\
\hline 5 & 0 & 0 & 0 & 0 & 1 & 0 & 0 & 0 & 0 & 0 & 0 & 0 & 0 & 0 & 0 & 0 & 0 & 0 \\
\hline 6 & 0 & 1 & 0 & 0 & 0 & 1 & 0 & 0 & 0 & 0 & 0 & 0 & 0 & 0 & 0 & 0 & 0 & 0 \\
\hline 7 & 1 & 0 & 1 & 1 & 1 & 0 & 1 & 1 & 1 & 1 & 0 & 0 & 0 & 1 & 0 & 0 & 0 & 0 \\
\hline 8 & 1 & 1 & 1 & 0 & 1 & 0 & 0 & 1 & 1 & 0 & 0 & 0 & 0 & 0 & 0 & 0 & 0 & 0 \\
\hline 9 & 0 & 0 & 1 & 0 & 0 & 0 & 0 & 0 & 1 & 1 & 0 & 0 & 0 & 1 & 0 & 0 & 0 & 0 \\
\hline 10 & 1 & 0 & 1 & 1 & 1 & 0 & 0 & 0 & 1 & 1 & 0 & 0 & 0 & 0 & 0 & 0 & 0 & 0 \\
\hline 11 & 0 & 0 & 0 & 0 & 1 & 0 & 1 & 0 & 0 & 0 & 1 & 0 & 0 & 1 & 0 & 1 & 0 & 1 \\
\hline 12 & 1 & 0 & 0 & 0 & 0 & 0 & 1 & 1 & 0 & 1 & 0 & 1 & 1 & 1 & 1 & 1 & 0 & 0 \\
\hline 13 & 1 & 0 & 1 & 0 & 0 & 0 & 1 & 1 & 1 & 1 & 0 & 0 & 1 & 1 & 0 & 0 & 1 & 0 \\
\hline 14 & 1 & 0 & 0 & 1 & 1 & 1 & 0 & 0 & 1 & 1 & 0 & 0 & 0 & 1 & 0 & 0 & 0 & 0 \\
\hline 15 & 0 & 0 & 0 & 0 & 0 & 0 & 0 & 0 & 0 & 0 & 1 & 1 & 1 & 0 & 1 & 1 & 1 & 1 \\
\hline 16 & 0 & 0 & 1 & 1 & 1 & 1 & 0 & 0 & 0 & 1 & 0 & 1 & 1 & 1 & 1 & 1 & 0 & 0 \\
\hline 17 & 0 & 1 & 0 & 1 & 1 & 0 & 0 & 0 & 1 & 0 & 0 & 1 & 1 & 1 & 1 & 0 & 1 & 0 \\
\hline 18 & 0 & 0 & 0 & 0 & 0 & 0 & 0 & 0 & 0 & 1 & 1 & 0 & 0 & 1 & 0 & 1 & 0 & 1 \\
\hline
\end{tabular}

Table 5. SSIM of research variables for ISM design

\begin{tabular}{|c|c|c|c|c|c|c|c|c|c|c|c|c|c|c|c|c|c|c|c|}
\hline & 1 & 2 & 3 & 4 & 5 & 6 & 7 & 8 & 9 & 10 & 11 & 12 & 13 & 14 & 15 & 16 & 17 & 18 & $\begin{array}{l}\text { Driving } \\
\text { power }\end{array}$ \\
\hline 1 & & 1 & 0 & 1 & 1 & 0 & 0 & 0 & 0 & 0 & 0 & 0 & 0 & 0 & 0 & 0 & 0 & 0 & 4 \\
\hline 2 & 0 & & 0 & 0 & 1 & 0 & 0 & 0 & 0 & 0 & 0 & 0 & 0 & 0 & 0 & 0 & 0 & 0 & 2 \\
\hline 3 & 1 & 1 & & $1^{*}$ & $1^{*}$ & $1^{\star}$ & $1^{*}$ & $1^{*}$ & 1 & 1 & $1^{*}$ & $1^{*}$ & $1^{\star}$ & 1 & $1^{*}$ & $1^{*}$ & $1^{*}$ & $1^{*}$ & 18 \\
\hline 4 & 0 & 1 & 0 & & 1 & 0 & 0 & 0 & 0 & 0 & 0 & 0 & 0 & 0 & 0 & 0 & 0 & 0 & 3 \\
\hline 5 & 0 & 0 & 0 & 0 & & 0 & 0 & 0 & 0 & 0 & 0 & 0 & 0 & 0 & 0 & 0 & 0 & 0 & 1 \\
\hline 6 & 0 & 1 & 0 & 0 & 0 & & $1^{*}$ & 0 & 0 & 0 & 0 & 0 & 0 & 0 & 0 & 0 & 0 & 0 & 3 \\
\hline 7 & 1 & $1^{*}$ & 1 & 1 & 1 & $1^{\star}$ & & 1 & 1 & 1 & $1^{*}$ & $1^{\star}$ & $1^{\star}$ & 1 & $1^{*}$ & $1^{\star}$ & $1^{*}$ & $1^{*}$ & 18 \\
\hline 8 & 1 & 1 & 1 & $1^{*}$ & 1 & $1^{*}$ & $1^{*}$ & & 1 & $1^{*}$ & $1^{\star}$ & $1^{\star}$ & $1^{\star}$ & $1^{*}$ & $1^{\star}$ & $1^{\star}$ & $1^{*}$ & $1^{*}$ & 18 \\
\hline 9 & $1^{*}$ & $1^{*}$ & 1 & $1^{*}$ & $1^{*}$ & $1^{*}$ & $1^{*}$ & $1^{*}$ & & 1 & $1^{*}$ & $1^{\star}$ & $1^{\star}$ & 1 & $1^{*}$ & $1^{*}$ & $1^{*}$ & $1^{*}$ & 18 \\
\hline 10 & 1 & $1^{*}$ & 1 & 1 & 1 & $1^{*}$ & $1^{*}$ & $1^{*}$ & 1 & & $1^{*}$ & $1^{*}$ & $1^{*}$ & $1^{*}$ & $1^{*}$ & $1^{*}$ & $1^{*}$ & $1^{*}$ & 18 \\
\hline 11 & $1^{*}$ & $1^{*}$ & $1^{*}$ & $1^{*}$ & 1 & $1^{*}$ & 1 & $1^{*}$ & $1^{*}$ & $1^{*}$ & & $1^{*}$ & $1^{\star}$ & 1 & $1^{*}$ & 1 & $1^{*}$ & 1 & 18 \\
\hline 12 & 1 & $1^{*}$ & $1^{*}$ & $1^{*}$ & $1^{*}$ & $1^{*}$ & 1 & 1 & $1^{*}$ & 1 & $1^{*}$ & & 1 & 1 & 1 & 1 & $1^{*}$ & $1^{*}$ & 18 \\
\hline 13 & 1 & $1^{*}$ & 1 & $1^{*}$ & $1^{*}$ & $1^{*}$ & 1 & 1 & 1 & 1 & $1^{*}$ & $1^{*}$ & & 1 & $1^{*}$ & $1^{*}$ & 1 & $1^{*}$ & 18 \\
\hline 14 & 1 & $1^{*}$ & $1^{*}$ & 1 & 1 & 1 & $1^{*}$ & $1^{*}$ & 1 & 1 & $1^{*}$ & $1^{\star}$ & $1^{\star}$ & & $1^{*}$ & $1^{*}$ & $1^{*}$ & $1^{*}$ & 18 \\
\hline 15 & $1^{*}$ & $1^{*}$ & $1^{*}$ & $1^{*}$ & $1^{*}$ & $1^{*}$ & $1^{*}$ & $1^{*}$ & $1^{*}$ & $1^{*}$ & 1 & 1 & 1 & $1^{*}$ & & 1 & 1 & 1 & 18 \\
\hline 16 & $1^{*}$ & $1^{*}$ & 1 & 1 & 1 & 1 & $1^{*}$ & $1^{*}$ & $1^{*}$ & 1 & $1^{*}$ & 1 & 1 & 1 & 1 & & $1^{*}$ & $1^{*}$ & 18 \\
\hline 17 & $1^{*}$ & 1 & $1^{\star}$ & 1 & 1 & $1^{*}$ & $1^{*}$ & $1^{*}$ & 1 & $1^{*}$ & $1^{*}$ & 1 & 1 & 1 & 1 & $1^{*}$ & & $1^{*}$ & 18 \\
\hline 18 & $1^{*}$ & $1^{*}$ & $1^{*}$ & $1^{*}$ & $1^{*}$ & $1^{*}$ & $1^{*}$ & $1^{*}$ & $1^{*}$ & 1 & 1 & $1^{*}$ & $1^{*}$ & 1 & $1^{*}$ & 1 & $1^{*}$ & & 18 \\
\hline Dependence & 14 & 17 & 13 & 15 & 17 & 14 & 14 & 13 & 13 & 13 & 13 & 13 & 13 & 13 & 13 & 13 & 13 & 13 & \\
\hline
\end{tabular}




\subsection{Determining criteria levels and priorities}

Based on the performance evaluation criteria for new service development and the final matrix derived from the expert analysis, the levels associated with each criterion are to be studied and analysed. As described in the ISM analysis, different levels of the model have been analysed. In this line, the cause and effect criteria related to each criterion are identified and then prioritized based on the methodology of interpretive structural modelling (Figure 2). Table 6 shows the levels of these criteria. As it can be found, Criterion 5 (return on investment) is placed at the first level; i.e., the highest position in the model. Criteria 3, 7-18 are ranked at the lowest positions in the model and obtained the fifth level.

\subsection{Criteria weighting and prioritize using ANP}

In this section, the criteria derived from the ISM analysis are weighted by the hierarchical analysis process. In addition, the relative importance of each criterion is also determined. Compared to other MADM techniques, the reason for the application of ANP arises from internal relationships of variables. In this line, evaluation criteria for NSD performance are grouped using a balanced scorecard model, and the weighting values are calculated through the ANP method. Here, expert opinions and the research questionnaire were employed for weighting the criteria.

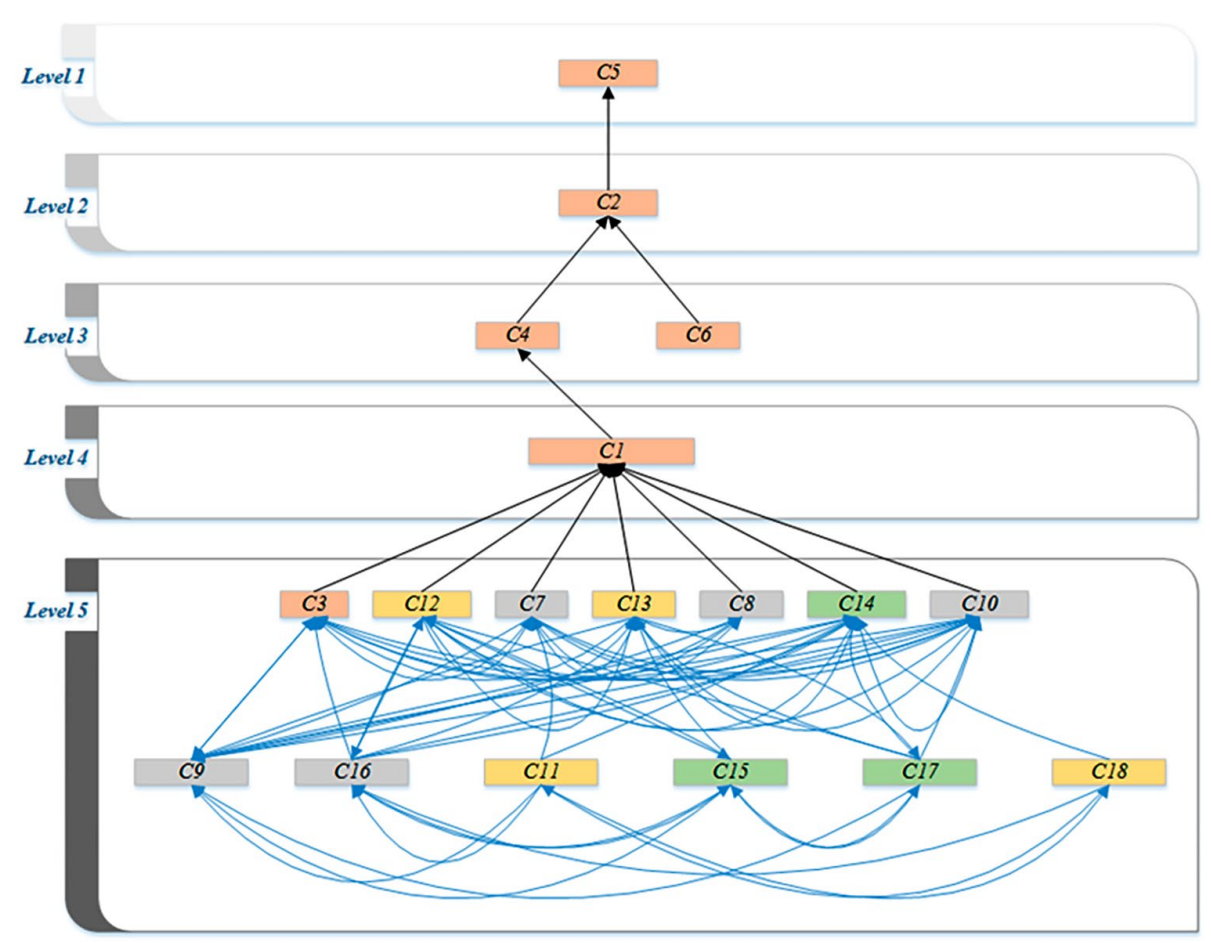

Figure 2. Final performance evaluation model for new service development in healthcare industry using ISM 
Table 6. Levels assigned to criteria

\begin{tabular}{|c|l|c|}
\hline Code & \multicolumn{1}{|c|}{ Criteria } & Criteria level in model \\
\hline 5 & Return on investment & Level 1 \\
\hline 2 & Profit & Level 2 \\
\hline 4 & Revenues from new service & Level 3 \\
\hline 6 & Implementation costs & Level 4 \\
\hline 1 & Sales and new service delivery & \\
\hline 3 & Market share & \\
\hline 7 & Customer satisfaction & \\
\hline 8 & Customer loyalty & \\
\hline 9 & brand value & Level 5 \\
\hline 10 & New customer attraction & \\
\hline 11 & Reduced lag time and effective implementation & \\
\hline 12 & Service applicability & \\
\hline 13 & Quality of service & \\
\hline 14 & Creating a competitive advantage & \\
\hline 15 & Knowledge gained from new service process & \\
\hline 16 & General service status over competitors & \\
\hline 17 & Percent of successful projects & \\
\hline 18 & Rate of service development against competitors & \\
\hline & & \\
\hline
\end{tabular}

Table 2 shows the categorization on these criteria (see Appendix for description of ANP methodology).

Accordingly, Figure 3 shows the relationship network model by relationships obtained from the ISM analysis. This model is known as the analytical network process (ANP) structure. The structure has four types of relationship: between strategic objective with model dimensions (IW21), between dimensions with model dimensions (IW22), between model dimensions and criteria (IW32) and mutual relationship of criteria (IW33).

First, in order to assess the importance and weighting of the criteria by using the ANP method, a research questionnaire is designed based on the relationships between the criteria. Then, it is completed by an expert panel consisting of three experts of NSD in healthcare field; all of them are managers of different hospitals in Tehran.

When the completed questionnaires received, the model derived from the ISM analysis is plotted in the Super Decision software environment. The aggregated opinions from each working groups are also identified in the software environment and the analysis required for each group is obtained. The output shows three main parts; unweighted inhomogeneous, weighted super matrices, dimensional weights, and variable weights. The weighting values of each criterion based on the first to third working groups, as well as the mean weighted values are shown in Table 7. Moreover, geometric mean values are used to calculate initial weights of the criteria. 


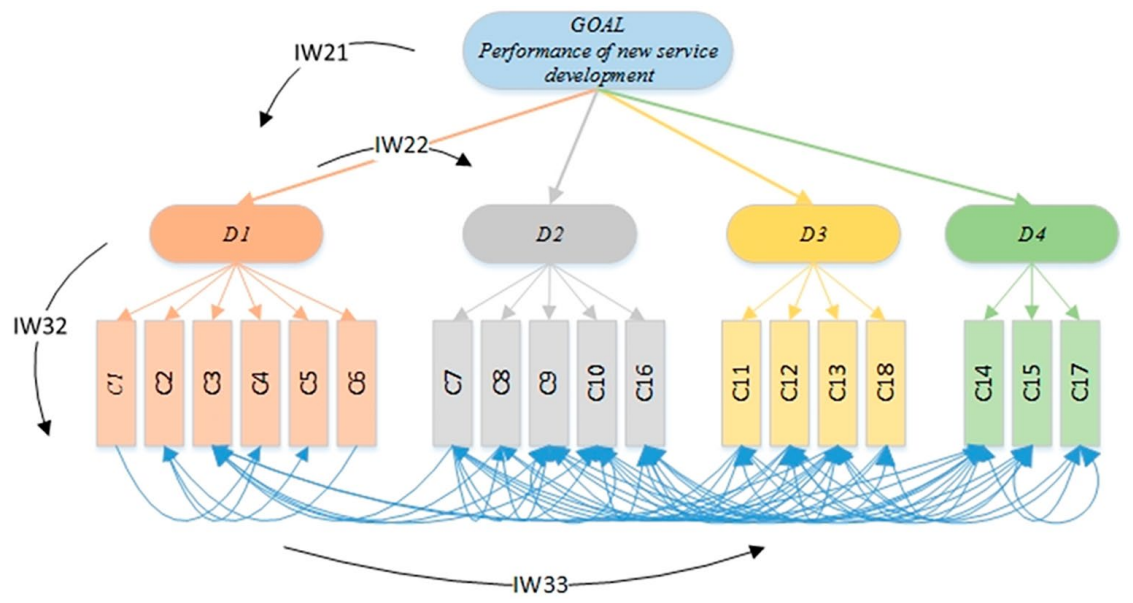

Figure 3. ANP structure

Table 7. Weighted matrix based on expert opinions

\begin{tabular}{|c|c|c|c|c|c|c|c|}
\hline 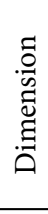 & 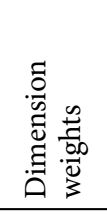 & 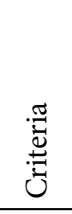 & 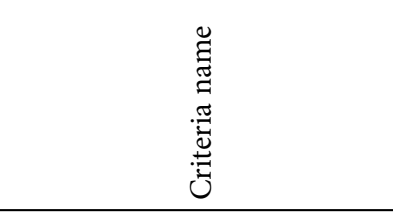 & 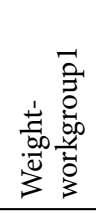 & 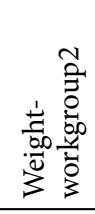 & 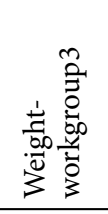 & 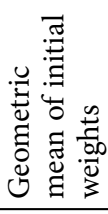 \\
\hline \multirow{6}{*}{ D1 } & \multirow{6}{*}{0.1619} & $\mathrm{C} 1$ & Sales and new service delivery & 0.0196 & 0.0218 & 0.2562 & 0.0222 \\
\hline & & $\mathrm{C} 2$ & Profit & 0.0446 & 0.0500 & 0.0506 & 0.0483 \\
\hline & & $\mathrm{C} 3$ & Market share & 0.0972 & 0.0984 & 0.0837 & 0.0927 \\
\hline & & $\mathrm{C} 4$ & Revenues from new service & 0.0227 & 0.0253 & 0.0375 & 0.0278 \\
\hline & & $\mathrm{C} 5$ & Return on investment & 0.0934 & 0.0953 & 0.0978 & 0.0955 \\
\hline & & C6 & Implementation costs & 0.0060 & 0.0066 & 0.0063 & 0.0063 \\
\hline \multirow{5}{*}{$\mathrm{D} 2$} & \multirow{5}{*}{0.4923} & $\mathrm{C} 7$ & Customer satisfaction & 0.0240 & 0.0396 & 0.0237 & 0.0282 \\
\hline & & $\mathrm{C} 8$ & Customer loyalty & 0.0023 & 0.0097 & 0.0124 & 0.0065 \\
\hline & & $\mathrm{C} 9$ & brand value & 0.3428 & 0.2912 & 0.2924 & 0.3079 \\
\hline & & $\mathrm{C} 10$ & New customer attraction & 0.2610 & 0.2613 & 0.2720 & 0.2647 \\
\hline & & $\mathrm{C} 16$ & General service status & 0.0004 & 0.0008 & 0.0012 & 0.0007 \\
\hline \multirow{4}{*}{ D3 } & \multirow{4}{*}{0.1899} & $\mathrm{C} 11$ & $\begin{array}{l}\text { Reduced lag time and } \\
\text { effectiveness implementation }\end{array}$ & 0.0004 & 0.0006 & 0.0011 & 0.0006 \\
\hline & & $\mathrm{C} 12$ & Service applicability & 0.0034 & 0.0028 & 0.0039 & 0.0033 \\
\hline & & $\mathrm{C} 13$ & Quality of service & 0.0061 & 0.0083 & 0.0097 & 0.0078 \\
\hline & & $\mathrm{C} 18$ & Rate of service development & 0.0002 & 0.0003 & 0.0002 & 0.0002 \\
\hline \multirow{3}{*}{ D4 } & \multirow{3}{*}{0.1453} & $\mathrm{C} 14$ & $\begin{array}{l}\text { Creating a competitive } \\
\text { advantage }\end{array}$ & 0.0744 & 0.0857 & 0.0790 & 0.0796 \\
\hline & & $\mathrm{C} 15$ & $\begin{array}{l}\text { Knowledge gained from new } \\
\text { service process }\end{array}$ & 0.0002 & 0.0007 & 0.0002 & 0.0003 \\
\hline & & $\mathrm{C} 17$ & Percent of successful projects & 0.0009 & 0.0013 & 0.0027 & 0.0014 \\
\hline
\end{tabular}


After calculating the geometric mean from the initial weights of all criteria, the weights of sub-criteria are to be normalized within each category. Then, the weight of each dimension is multiplied by the normalized weight of the criteria and so the final weights are obtained.

Table 8 shows the values of dimensional weights, normalized weight of sub-criteria, and final weight of the sub-criteria.

Table 8. Final weights and normalized weights based on expert opinions

\begin{tabular}{|c|c|c|c|c|c|c|}
\hline & $\begin{array}{l}\text { Dimension } \\
\text { weights }\end{array}$ & Criteria & Criteria name & $\begin{array}{l}\text { Mean of initial } \\
\text { normal weight }\end{array}$ & $\begin{array}{c}\text { Final } \\
\text { weight }\end{array}$ & Ranking \\
\hline \multirow{6}{*}{ D1 } & \multirow{6}{*}{0.1619} & $\mathrm{C} 1$ & Sales and new service delivery & 0.07579 & 0.01227 & 11 \\
\hline & & $\mathrm{C} 2$ & Profit & 0.16507 & 0.02672 & 8 \\
\hline & & $\mathrm{C} 3$ & Market share & 0.31646 & 0.05123 & 7 \\
\hline & & $\mathrm{C} 4$ & Revenues from new service & 0.09509 & 0.01539 & 10 \\
\hline & & C5 & Return on investment & 0.32588 & 0.05276 & 5 \\
\hline & & C6 & Implementation costs & 0.02168 & 0.00351 & 15 \\
\hline \multirow{5}{*}{$\mathrm{D} 2$} & \multirow{5}{*}{0.4923} & $\mathrm{C} 7$ & Customer satisfaction & 0.04643 & 0.02286 & 9 \\
\hline & & $\mathrm{C} 8$ & Customer loyalty & 0.01071 & 0.00527 & 13 \\
\hline & & C9 & brand value & 0.50631 & 0.24928 & 1 \\
\hline & & $\mathrm{C} 10$ & New customer attraction & 0.43534 & 0.21434 & 2 \\
\hline & & $\mathrm{C} 16$ & General service status & 0.00119 & 0.00058 & 17 \\
\hline \multirow{4}{*}{ D3 } & \multirow{4}{*}{0.1899} & C11 & $\begin{array}{l}\text { Reduced lag time and } \\
\text { effectiveness implementation }\end{array}$ & 0.05299 & 0.01006 & 12 \\
\hline & & $\mathrm{C} 12$ & Service applicability & 0.2756 & 0.05234 & 6 \\
\hline & & $\mathrm{C} 13$ & Quality of service & 0.65247 & 0.12391 & 4 \\
\hline & & $\mathrm{C} 18$ & Rate of service development & 0.01891 & 0.00359 & 14 \\
\hline \multirow{3}{*}{ D4 } & \multirow{3}{*}{0.1453} & C14 & $\begin{array}{l}\text { Creating a competitive } \\
\text { advantage }\end{array}$ & 0.97817 & 0.14215 & 3 \\
\hline & & $\mathrm{C} 15$ & $\begin{array}{l}\text { Knowledge gained from new } \\
\text { service process }\end{array}$ & 0.00373 & 0.00054 & 18 \\
\hline & & $\mathrm{C} 17$ & Percent of successful projects & 0.01809 & 0.00263 & 16 \\
\hline
\end{tabular}

\section{Discussion}

In this section, the results of previous step in Moheb hospital are discussed first. With regard to the average weights obtained in Table 8 , the priority of each criterion is identified among all criteria within the performance evaluation model of new service development in the healthcare industry, according to the opinion of experts. As it can be seen in Table 8, the most important category is customer-related measures (approximate weight of 0.49); this means that the customer's insight for the success of a new service is of great importance. The same result was previously explained (Blindenbach-Driessen et al., 2010; Storey \& Kelly, 2001). In this category, the most important criterion - brand value (C9) - has an approximate weight of 0.24 . With a very small margin from the first, the second most important criterion associ- 
ates with the criterion of new customer attraction (C10) with an approximate weight of 0.21 . However, the next two criteria are creating of a competitive advantage (C14) and the quality of service (C13), with similar weighting values by 0.14 and 0.12 , respectively. These criteria are covered at two categories of learning and growth, internal processes.

Now, it is necessary to assess the current conditions of all criteria in the hospital. To this end, the authors collected the views of all individuals involved in the NSD process in this hospital, as well as new service performance reports and documents provided by the Moheb hospital during a three-year period. The development process of new services in this hospital is organized as a group called the Thought Room.

In order to measure the performance criteria of new service development in the hospital under study based on the opinions from all people involved in the Thought Room, each criterion is assigned a number in the range of $0-100$. The radar chart shown in Figure 4 illustrates the status of the hospital for each criteria of the model. The criteria in each category are marked with a separated colour. This chart indicates that the status of the new service development performance in Moheb hospital is moderate. The minimum performance rating assigned to the criteria is $45.8 \%$, corresponding to the percentage of successful projects in this hospital over the past three years; the while the maximum score of $59.5 \%$ is allocated to the knowledge gained from the new service process. Such a high rate is related to the proper knowledge management at the hospital level.

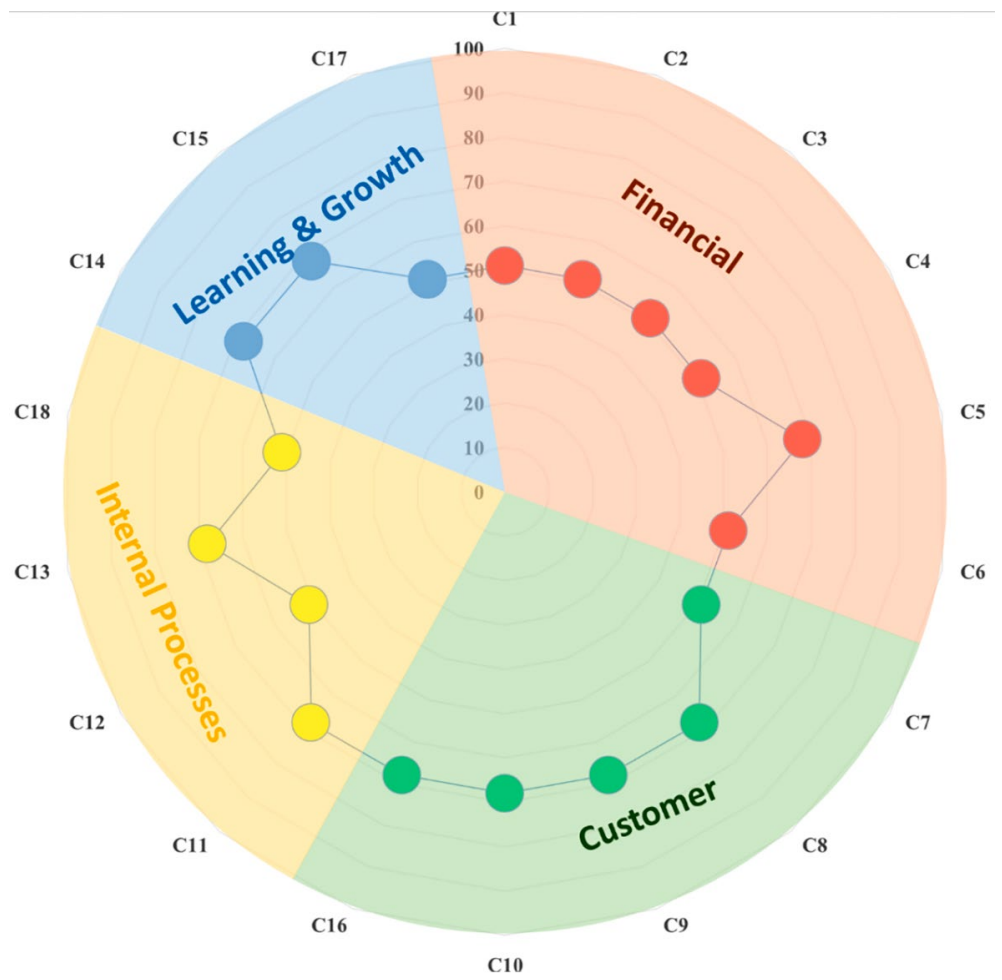

Figure 4. Radar chart for hospital performance in terms of model criteria 
Now, by examining the existing situation and integrating the model with the weighting values obtained from the hierarchical analysis method, the overall performance of the hospital is measured for each criterion. Since the performance evaluation is scaled from zero to 100 , the weights are multiplied by 100 and also measured at a scale of 0 to 100 . Table 9 shows how to calculate this score for the performance of the Moheb Hospital. In this case, the weight of each criterion is multiplied by the score achieved and then all scores are summed. The output is a number from 0 and 100, which represents the ultimate score for the hospital's performance. Table 9 shows how the final score of hospital status has been obtained.

Table 9. Hospital status for each criterion

\begin{tabular}{|c|c|c|c|c|c|c|c|}
\hline & Criteria & Criteria name & $\begin{array}{c}\text { Final } \\
\text { weight }\end{array}$ & $\begin{array}{c}\mathrm{A}= \\
\text { Weights }{ }^{\star} 100\end{array}$ & $\begin{array}{c}\mathrm{B}=\text { Criteria } \\
\text { score (from } \\
\text { Moheb Thought } \\
\text { Room) }\end{array}$ & $A^{\star} B$ & $\begin{array}{l}\text { Final } \\
\text { score }\end{array}$ \\
\hline \multirow{6}{*}{ D1 } & $\mathrm{C} 1$ & $\begin{array}{l}\text { Sales and new service } \\
\text { delivery }\end{array}$ & 0.01227 & 1.227 & 50.3 & 61.7181 & \multirow{18}{*}{  } \\
\hline & $\mathrm{C} 2$ & Profit & 0.02673 & 2.673 & 50 & 133.65 & \\
\hline & $\mathrm{C} 3$ & Market share & 0.05124 & 5.124 & 49.8 & 255.1752 & \\
\hline & $\mathrm{C} 4$ & $\begin{array}{l}\text { Revenues from new } \\
\text { service }\end{array}$ & 0.0154 & 1.540 & 49.2 & 75.768 & \\
\hline & C5 & Return on investment & 0.05276 & 5.276 & 52.1 & 274.8796 & \\
\hline & C6 & Implementation costs & 0.00351 & 0.351 & 46.8 & 16.4268 & \\
\hline \multirow{5}{*}{ D2 } & $\mathrm{C} 7$ & Customer satisfaction & 0.02286 & 2.286 & 52 & 118.872 & \\
\hline & $\mathrm{C} 8$ & Customer loyalty & 0.00528 & 0.528 & 57.8 & 30.5184 & \\
\hline & C9 & brand value & 0.24929 & 24.929 & 56.6 & 1410.9814 & \\
\hline & $\mathrm{C} 10$ & $\begin{array}{l}\text { New customer } \\
\text { attraction }\end{array}$ & 0.21434 & 21.434 & 57.8 & 1238.8852 & \\
\hline & $\mathrm{C} 16$ & General service status & 0.00059 & 0.059 & 52.1 & 3.0739 & \\
\hline \multirow{4}{*}{ D3 } & C11 & $\begin{array}{l}\text { Reduced lag time } \\
\text { and effectiveness } \\
\text { implementation }\end{array}$ & 0.01007 & 1.007 & 49.1 & 49.4437 & \\
\hline & $\mathrm{C} 12$ & Service applicability & 0.05234 & 5.234 & 49.6 & 259.6064 & \\
\hline & $\mathrm{C} 13$ & Quality of service & 0.12392 & 12.392 & 53.7 & 665.4504 & \\
\hline & $\mathrm{C} 18$ & $\begin{array}{l}\text { Rate of service } \\
\text { development }\end{array}$ & 0.00359 & 0.359 & 48.3 & 17.3397 & \\
\hline \multirow{3}{*}{$\mathrm{D} 4$} & $\mathrm{C} 14$ & $\begin{array}{l}\text { Creating a } \\
\text { competitive } \\
\text { advantage }\end{array}$ & 0.14215 & 14.215 & 57.1 & 811.6765 & \\
\hline & C15 & $\begin{array}{l}\text { Knowledge gained } \\
\text { from new service } \\
\text { process }\end{array}$ & 0.00054 & 0.054 & 59.8 & 3.2292 & \\
\hline & $\mathrm{C} 17$ & $\begin{array}{l}\text { Percent of successful } \\
\text { projects }\end{array}$ & 0.00263 & 0.263 & 45.8 & 12.0454 & \\
\hline \multicolumn{6}{|c|}{$\operatorname{SUM}\left(A^{\star} B\right)$} & 5438.73 & \\
\hline & sc & the perform & NSI & Aoheb h & & & 54.38 \\
\hline
\end{tabular}




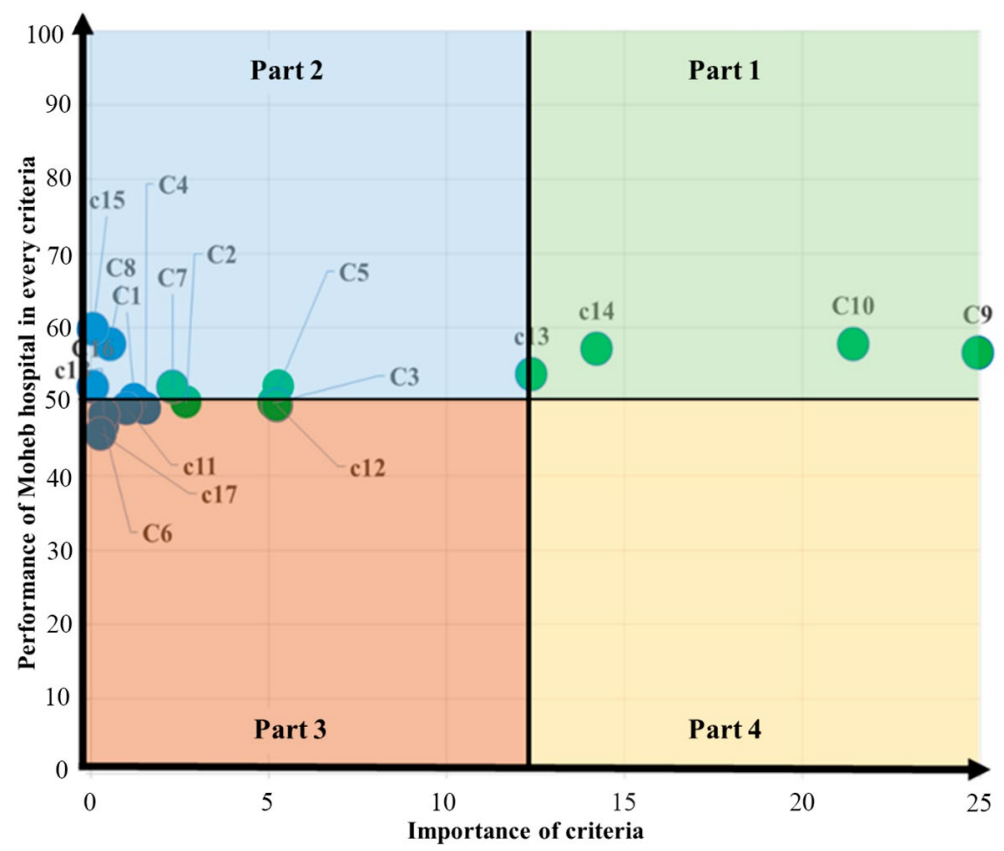

Figure 5. Hospital performance framework for new service development

Given that the performance of Moheb Hospital was measured as a pilot project, the score obtained for this hospital was evaluated in the given range. The performance of Moheb Hospital is 54.38 out of 100 points.

Figure 5 shows the status of Moheb Hospital in terms of performance evaluation criteria for new service development in the healthcare industry. In this figure, the performance of the hospital in each criterion is shown on the vertical axis, whereas the importance of each criterion (based on the weight calculated for that criterion) is determined on the horizontal axis. Data related to each criterion are derived from the two columns of Final weight and Criteria score shown in Table 9. Given that the highest and the lowest score of importance (weight of the criteria) are approximately 0.25 and zero, respectively; the horizontal axis covers the distance between these two values. On the other hand, given that the service development performance score is between zero and 100, the vertical axis covers this range.

As shown in Figure 5, the four criteria of brand value (C9), new customer attraction (C10), creating of competitive advantage (C14) and the quality of services (C13) are placed in Part 1. Since this category of criteria has a more relative importance in terms of performance evaluation for new service development, so if the organization focuses on improving the status of these criteria, more effectiveness will be achieved. Considering that the performance of Moheb hospital based on these criteria is at an approximately moderate level; in the later stages, it is necessary to plan more precisely in order to improve hospital performance based on these criteria. To this end, investment should be done appropriately to define and implement improvement projects. 


\section{Conclusions}

Undoubtedly, services have a significant share in the economic development of different countries, especially developing countries. Accordingly, the issue of developing new services is one of the most important concerns of policy makers in the national industry and managers at the enterprise level. New service development refers to a key strategic factor in creating value to enhance the profitability of existing customers and motivate prospects. As one of the largest and fastest-growing industries, the healthcare industry has no exception. Since the development of new services and/or products is created through a variety of perspectives and methods, the performance evaluation and success assessment of a new service/ product development is very important. The most important achievement of this research is the provision of a framework for measuring NSD performance. Therefore, it was tried to integrate the various criteria mentioned in previous research and to categorize them in the form of an agreed approach such as BSC. Then, these criteria were localized with the help of managers and experts in the healthcare industry. In order to explain how to apply this framework in practice, we tried to implement the introduced steps in the form of a case study (Moheb Hospital).

Accordingly, the present study tries to address some gaps identified from literature review through an integrated application of ANP and ISM methods. Therefore, the innovations of the current research can be introduced in the form of three main categories; First, identification of NSD performance measures based on a comprehensive literature review, their localization in the healthcare industry, and the use of a balanced scorecard methodology to improve the accuracy and completeness of performance measures. Second, determining relationships among criteria using the ISM method and calculating weights and importance levels of each dimension and criterion using the ANP method. Finally, the third innovation is to provide a framework for proposing improvements based on the two dimensions of importance and status of each of the criteria in the case study.

\section{Limitations}

New services Development in healthcare industry in Iran is not long ago. Hence, few hospitals have implemented the new service development process. Therefore, in this study, it was not possible to compare different hospitals and evaluate them. Also, due to the lack of similarity and homogeneity between the new service projects in the Mohab Hospital, this research cannot be implemented at the project analysis level.

From the practical point of view, given that the managers of the Mohab Hospital were generally composed of doctors and did not have sufficient familiarity with the managerial approaches, therefore, it was difficult to interact with the managers regarding the implementation of the framework provided in this research, and it took months. 


\section{Suggestions}

The final score of the hospital's performance in the new service development was about 54 out of 100 points, which shows a moderate performance. Since the beginning of new service development at Moheb hospital takes a time frame of less than five years, it provides an acceptable level of performance. In future periods, the hospital can make significant performance improvements by selecting appropriate strategies and practices. This requires to deal with more important and higher-value criteria as well as to consider criteria of lesser importance as research objectives, while achieving superior levels of performance in future.

Some of the identified criteria are qualitative in nature and linguistic variables have been used to measure them. Hence, fuzzy sets or interval-valued intuitionistic fuzzy sets can be used in order to reduce the amount of ambiguity in the calculations. Also, because the evaluation of some criteria requires special expertise, the evaluations performed by the experts have a level of uncertainty and hesitation. Therefore, approaches that take advantage of hesitant fuzzy sets can be used to re-model this problem.

\section{References}

Agarwal, A., Shankar, R., \& Tiwari, M. K. (2007). Modeling agility of supply chain. Industrial Marketing Management, 36(4), 443-457. https://doi.org/10.1016/j.indmarman.2005.12.004

Azar, A., Tizro, A., Moghbel, A., \& Rostami, A. A. R. (2010). Designing supply chain agile model: Interpretive structural modeling approach. Management Researches in Iran, 14(4), 1-25.

Behdioğlu, S., Acar, E., \& Burhan, H. A. (2019). Evaluating service quality by fuzzy SERVQUAL: A case study in a physiotherapy and rehabilitation hospital. Total Quality Management \& Business Excellence, 30(3-4), 301-319. https://doi.org/10.1080/14783363.2017.1302796

Bendoly, E., Bharadwaj, A., \& Bharadwaj, S. (2012). Complementary drivers of new product development performance: Cross-functional coordination, information system capability, and intelligence quality. Production and Operations Management, 21(4), 653-667. https://doi.org/10.1111/j.1937-5956.2011.01299.x

Blindenbach-Driessen, F., van Dalen, J., \& van den Ende, J. (2010). Subjective performance assessment of innovation projects. Journal of Product Innovation Management, 27(4), 572-592.

https://doi.org/10.1111/j.1540-5885.2010.00736.x

Busagara, T., Mori, N., Mossberg, L., Jani, D., \& Andersson, T. (2020). Customer information sharing and new service development: Is there a link? The Bottom Line, 33(2), 133-147.

https://doi.org/10.1108/BL-09-2019-0112

Chan, C. V., \& Kaufman, D. R. (2010). A technology selection framework for supporting delivery of patient-oriented health interventions in developing countries. Journal of Biomedical Informatics, 43(2), 300-306. https://doi.org/10.1016/j.jbi.2009.09.006

Cheng, C. C., \& Krumwiede, D. (2012). The role of service innovation in the market orientation - new service performance linkage. Technovation, 32(7-8), 487-497.

https://doi.org/10.1016/j.technovation.2012.03.006

Cheng, F., Lin, M., Yüksel, S., Dİncer, H., \& Kalkavan, H. (2020). A hybrid hesitant 2-tuple IVSF decision making approach to analyze PERT-based critical paths of new service development process for renewable energy investment projects. IEEE Access, 9, 3947-3969.

https://doi.org/10.1109/ACCESS.2020.3048016 
Cowell, D. W. (1988). New service development. Journal of Marketing Management, 3(3), 296-312. https://doi.org/10.1080/0267257X.1988.9964048

De Jong, J. P. J., \& Vermeulen, P. A. M. (2003). Organizing successful new service development: A literature review. Management Decision, 41(9), 844-858. https://doi.org/10.1108/00251740310491706

Dinçer, H., \& Yüksel, S. (2018). Comparative evaluation of BSC-based new service development competencies in Turkish banking sector with the integrated fuzzy hybrid MCDM using content analysis. International Journal of Fuzzy Systems, 20(8), 2497-516. https://doi.org/10.1007/s40815-018-0519-y

Elg, M., Engström, J., Witell, L., \& Poksinska, B. (2012). Co-creation and learning in health-care service development. Journal of Service Management, 23(3), 328-343.

https://doi.org/10.1108/09564231211248435

Fiordelli, M., Diviani, N., \& Schulz, P. J. (2013). Mapping mHealth research: A decade of evolution. Journal of Medical Internet Research, 15(5), e95. https://doi.org/10.2196/jmir.2430

Fitzsimmons, J. A., \& Fitzsimmons, M. J. (2006). Service management: Operations, strategy, and information technology. McGraw-Hill/Irwin. https://books.google.lt/books/about/Service_Management. html?id=3Km1AAAAIAAJ\&redir_esc $=y$

Ghani, E., \& O'Connel, S. D. (2014). Can service be a growth escalator in low income countries? (Policy Research Working Paper 6971). https://doi.org/10.1596/1813-9450-6971

Giudici, G., Guerini, M., \& Rossi-Lamastra, C. (2019). The creation of cleantech startups at the local level: The role of knowledge availability and environmental awareness. Small Business Economics, 52(4), 815-830. https://doi.org/10.1007/s11187-017-9936-9

Gölcük, İ., \& Baykasoğlu, A. (2016). An analysis of DEMATEL approaches for criteria interaction handling within ANP. Expert Systems with Applications, 46, 346-366.

https://doi.org/10.1016/j.eswa.2015.10.041

Goswami, M., Daultani, Y., \& De, A. (2021). Decision modeling and analysis in new product development considering supply chain uncertainties: A multi-functional expert based approach. Expert Systems with Applications, 166, 114016. https://doi.org/10.1016/j.eswa.2020.114016

Jiménez-Zarco, A. I., Martínez-Ruiz, P., \& Izquierdo-Yusta, A. (2011). The impact of market orientation dimensions on client cooperation in the development of new service innovations. European Journal of Marketing, 45(1/2), 43-67. https://doi.org/10.1108/03090561111095595

Kaplan, R., \& Norton, D. (2005). The balanced scorecard: Measures That drive performance. Harvard Business Review, 83(7), 172. https://www.researchgate.net/publication/298043780_The_Balanced_ Scorecard_measures_that_drive_performance

Kim, K. J., \& Meiren, T. (2010). New service development process. In Introduction to service engineering (pp. 253-267). https://doi.org/10.1002/9780470569627.ch12

Kitsios, F., \& Kamariotou, M. (2020). Mapping new service development: A review and synthesis of literature. The Service Industries Journal, 40(9-10), 682-704. https://doi.org/10.1080/02642069.2018.1561876

Kriegel, J., Schmitt-Rüth, S., Güntert, B., \& Mallory, P. (2013). New service development in German and Austrian health care - bringing e-health services into the market. International Journal of Healthcare Management, 6(2), 77-86. https://doi.org/10.1179/2047971913Y.0000000034

Kumar, S., Luthra, S., Govindan, K., Kumar, N., \& Haleem, A. (2016). Barriers in green lean six sigma product development process: An ISM approach. Production Planning \& Control, 27(7-8), 604-620. https://doi.org/10.1080/09537287.2016.1165307

Lai, J., \& Yuen, P. L. (2019). Performance evaluation for hospital facility management: Literature review and a research methodology. Journal of Facility Management Education and Research, 3(1), 38-43. https://doi.org/10.22361/jfmer/96267

Lee, H., Kim, C., \& Park, Y. (2010). Evaluation and management of new service concepts: An ANPbased portfolio approach. Computers \& Industrial Engineering, 58(4), 535-543.

https://doi.org/10.1016/j.cie.2009.11.016 
Lee, S. M., Lee, D., \& Schniederjans, M. J. (2011). Supply chain innovation and organizational performance in the healthcare industry. International Journal of Operations \& Production Management, 31(11), 1193-1214. https://doi.org/10.1108/01443571111178493

Letina, I., Liu, S., \& Netzer, N. (2020). Delegating performance evaluation. Theoretical Economics, 15(2), 477-509. https://doi.org/10.3982/TE3570

Lima, L., \& Teixeira, J. G. (2020). The SDCS method: A new service design method for companies undergoing a servitization process. In Lecture notes in business information processing: Vol. 377. Exploring service science (pp. 245-258). Springer. https://doi.org/10.1007/978-3-030-38724-2_18

Lin, F.-R., \& Hsieh, P.-S. (2011). A SAT view on new service development. Service Science, 3(2), 141157. https://doi.org/10.1287/serv.3.2.141

Liu, C.-H., Chang, A. Y.-p., Horng, J.-S., Chou, S.-F., \& Huang, Y.-C. (2020). Co-competition, learning, and business strategy for new service development. The Service Industries Journal, 40(7-8), 585-609. https://doi.org/10.1080/02642069.2019.1571045

Major, I. (2019). Two-sided information asymmetry in the healthcare industry. International Advances in Economic Research, 25(2), 177-193. https://doi.org/10.1007/s11294-019-09732-9

Melton, H. L., \& Hartline, M. D. (2010). Customer and frontline employee influence on new service development performance. Journal of Service Research, 13(4), 411-425. https://doi.org/10.1177/1094670510369378

Melton, H. L., \& Hartline, M. D. (2013). Employee collaboration, learning orientation, and new service development performance. Journal of Service Research, 16(1), 67-81. https://doi.org/10.1177/1094670512462139

Menor, L. J., \& Roth, A. V. (2007). New service development competence in retail banking: Construct development and measurement validation. Journal of Operations Management, 25(4), 825-846. https://doi.org/10.1016/j.jom.2006.07.004

Menor, L. J., \& Roth, A. V. (2008). New service development competence and performance: An empirical investigation in retail banking. Production and Operations Management, 17(3), 267-284. https://doi.org/10.3401/poms.1080.0034

Mikolajczyk, K., \& Schmid, C. (2005). A performance evaluation of local descriptors. IEEE Transactions on Pattern Analysis and Machine Intelligence, 27(10), 1615-1630. https://doi.org/10.1109/TPAMI.2005.188

Pfohl, H. C., Gallus, P., \& Thomas, D. (2011). Interpretive structural modeling of supply chain risks. International Journal of Physical Distribution \& Logistics Management, 41(9), 839-859. https://doi.org/10.1108/09600031111175816

Price Waterhouse Cooper. (2014). Top Health Industry Issues of 2015 - A new health economy takes shape. https://www.kpcareerplanning.org/prd/include/pwc-hri-top-healthcare-issues-2015.pdf

Purohit, J. K., Mittal, M. L., Mittal, S., \& Kumar Sharma, M. (2016). Interpretive structural modelingbased framework for mass customisation enablers: An Indian footwear case. Production Planning \& Control, 27(9), 774-786. https://doi.org/10.1080/09537287.2016.1166275

Saaty, T. L. (1980). The analytic heirarchy process. Wiley StatsRef: Statistics Reference Online.

Saaty, T. L. (1996). Decision making with dependence and feedback: The analytic network process. RWS Publications.

Sartor, M. (2019). The Balanced Scorecard. In Quality management: Tools, methods, and standards (pp. 55-76). Emerald Publishing Limited. https://doi.org/10.1108/9781787698017

Shyu, J. Z., Wang, J. S., Peng, C. C., \& Tang, Y. H. (2012). Service innovation elements in Energy Service Company (ESCO) business model. Advanced Materials Research, 524, 3139-3153. https://doi.org/10.4028/www.scientific.net/AMR.524-527.3139

Storey, C., \& Kelly, D. (2001). Measuring the performance of new service development activities. Service Industries Journal, 21(2), 71-90. https://doi.org/10.1080/714005018 
Storey, C., \& Hughes, M. (2013). The relative impact of culture, strategic orientation and capability on new service development performance. European Journal of Marketing, 47(5/6), 833-856. https://doi.org/10.1108/03090561311306903

Tseng, M. L., Lin, Y. H., Lim, M. K., \& Teehankee, B. L (2015). Using a hybrid method to evaluate service innovation in the hotel industry. Applied Soft Computing, 28, 411-421. https://doi.org/10.1016/j.asoc.2014.11.048

Victorino, L., Verma, R., Plaschka, G., \& Dev, C. (2005). Service innovation and customer choices in the hospitality industry. Managing Service Quality: An International Journal, 15(6), 555-576. https://doi.org/10.1108/09604520510634023

Wamboye, E. F., \& Nyaronga, P. J. (2018). The service sector and economic development in Africa ( $1^{\text {st }}$ ed.). Routledge. https://doi.org/10.4324/9781315627373

Wang, W. P., \& Tang, M. C. (2012). Evaluating new service development performance based on multigranular linguistic assessment. International Journal of Mechanical, Aerospace, Industrial, Mechatronic and Manufacturing Engineering, 6(7), 1313-1318.

Warfield, J. N. (1974). Developing subsystem matrices in structural modeling. IEEE Transactions on Systems, Man, and Cybernetics, SMC-4(1), 74-80. https://doi.org/10.1109/TSMC.1974.5408523

Weng, R. H., \& Huang, C. Y. (2012). The impact of customer knowledge capability and relational capability on new service development performance: The case of health service. Journal of Management \& Organization, 18(5), 608-624. https://doi.org/10.5172/jmo.2012.18.5.608

Yeh, T.-M., Chen, S.-H., \& Chen, T.-F. (2019). The relationships among experiential marketing, service innovation, and customer satisfaction - A case study of tourism factories in Taiwan. Sustainability, 11(4), 1041. https://doi.org/10.3390/su11041041

Ying, C.-s., Li, Y.-L., Chin, K.-S., Yang, H.-T., \& Xu, J. (2018). A new product development concept selection approach based on cumulative prospect theory and hybrid-information MADM. Computers \& Industrial Engineering, 122, 251-261. https://doi.org/10.1016/j.cie.2018.05.023

\section{APPENDIX}

\section{Interpretative structural modeling}

Interpretative structural modelling is a methodology for creating and understanding the relationships between elements of a complex system. In other words, this analysis is an interactive process in which a variety of related elements are structured as a comprehensive systematic model (Warfield, 1974; Purohit et al., 2016).The ISM methodology makes a great contribution on establishing the order within complex relationships between elements of a given system. It allows identifying internal relationships between variables, and also prioritizing and analysing the impact of one variable on others. Also, this model can also prioritize and determine different levels in a given system, which is very helpful for managers to better implement the model (Warfield, 1974). Here, when the dimensions and criteria identified, the relationships between criteria are identified and then analysed by using a "lead" concept. Having decided the factor set and contextual relation, a structural self-interaction matrix (Giudici et al., 2019) is developed based on pairwise comparison of variables. This matrix can be described as follows: 


$$
S=\stackrel{e_{2}}{e_{1}} \underset{e_{m}}{e_{m}}\left[\begin{array}{cccc}
0 & e_{2} & \cdots & e_{n} \\
\pi_{21} & 0 & \cdots & \pi_{1 n} \\
\vdots & \vdots & \ddots & \vdots \\
\pi_{m 1} & z_{m 2} & \cdots & 0
\end{array}\right],
$$

where $e_{i}$ represents the $i_{\text {th }}$ element, $\pi_{i j}$ denotes the inter-relationship between the $i_{\text {th }}$ and $j_{\text {th }}$ elements, and $S$ denotes the SSIM. Modes and symbols used in this conceptual relationship are presented in Table 10.

Table 10. Symbols for ISM design

\begin{tabular}{|c|c|c|c|}
\hline $\mathrm{V}$ & $\mathrm{A}$ & $\mathrm{X}$ & $\mathrm{O}$ \\
\hline$j$ will effects on $\mathrm{i}$ & $i$ will effects on $j$ & Two-sided relationship & Without relationship \\
\hline
\end{tabular}

Interpretative structural modelling is a method that makes it possible to examine the complexity of a system and make it easily understandable (Agarwal et al., 2007; Kumar et al., 2016). According to Warfield (1974) - ISM developer - this procedure is an interactive learning process that constructs a variety of related factors in a comprehensive systematic model. Therefore, the application of ISM process needs an accurate implementation in any system (Azar et al., 2010). This process is shown in Figure 6 (Pfohl et al., 2011).

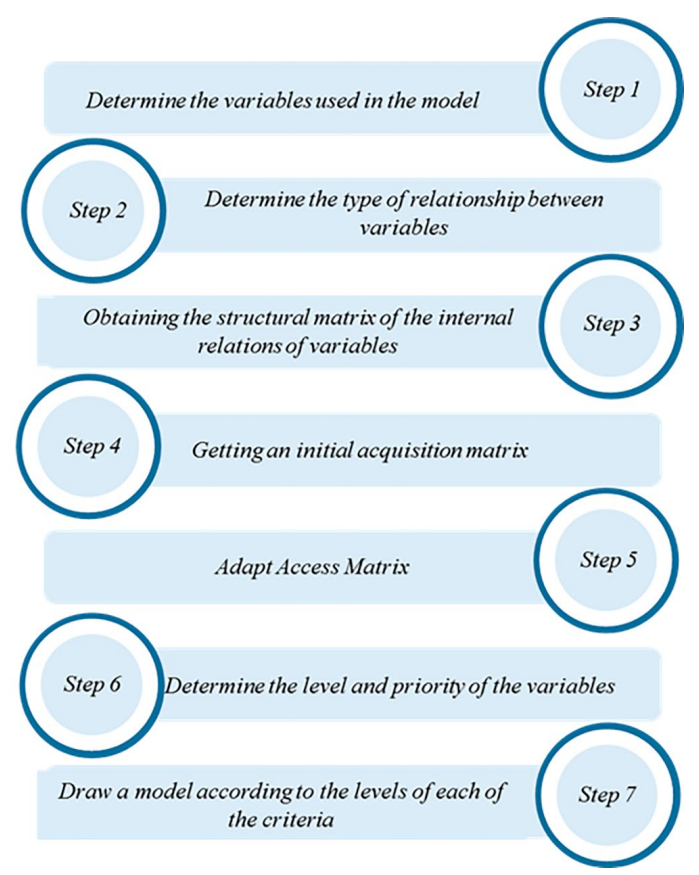

Figure 6. ISM steps 
In this study, the ISM method is used to identify relationships between the criteria. Due to their dependence, it is necessary to examine relationships and impact paths between criteria in order to accordingly measure the importance of each criterion using the ANP method. The ANP method concerns different relationships between variables and applied the pairwise comparison matrix for calculating the importance and weight for all criteria.

\section{Analytical network process}

Analytical network process (ANP) is a mathematical theory that systematically deals with all kinds of dependence and successfully applied in various fields. This methodology was developed by (Saaty, 1980) to provide priorities for decisions, with no hypothesis about one-sided hierarchical relationship between decision levels. The ANP method is based on human brain analysis for complex problems with non-intrusive structure, to modify the AHP method. It is used to model the network problems of the nodes in this network which include objectives, criteria, and alternatives. The vectors that connect these nodes indicate the effect of nodes on each other. The ANP technique is to model the decision-making problem by applying a system perspective coupled with feedback. Its comprehensive framework can consider all interactions and relationships between decision levels that constitute a network structure (Saaty, 1980). The process steps are summarized in the Figure 7.

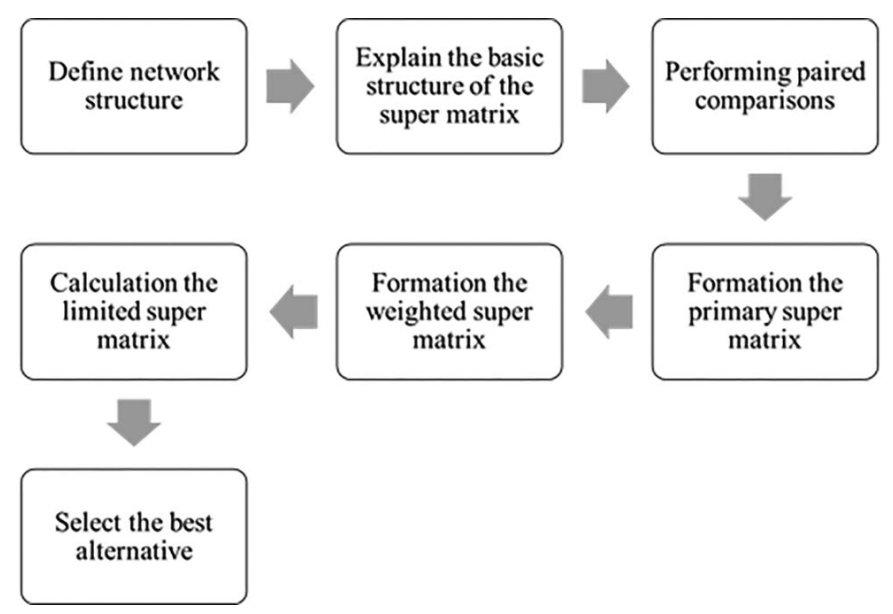

Figure 7. ANP steps

The principal concept of ANP is parallel to the Markov chain process with relative importance weights adjusted by forming a super matrix from eigenvectors of these relative importance weights. The super matrix expresses a relationship between two clusters in a system. Assume a system of $\mathrm{N}$ clusters or components; component $\mathrm{h}$, denoted by $C_{h}, h=1, \ldots, N$, has $n_{h}$ elements that we denote $e_{h 1}, e_{h 2}, \ldots, e_{h n h}$; then a standard form of super matrix can be formulated as Eq. (2): 


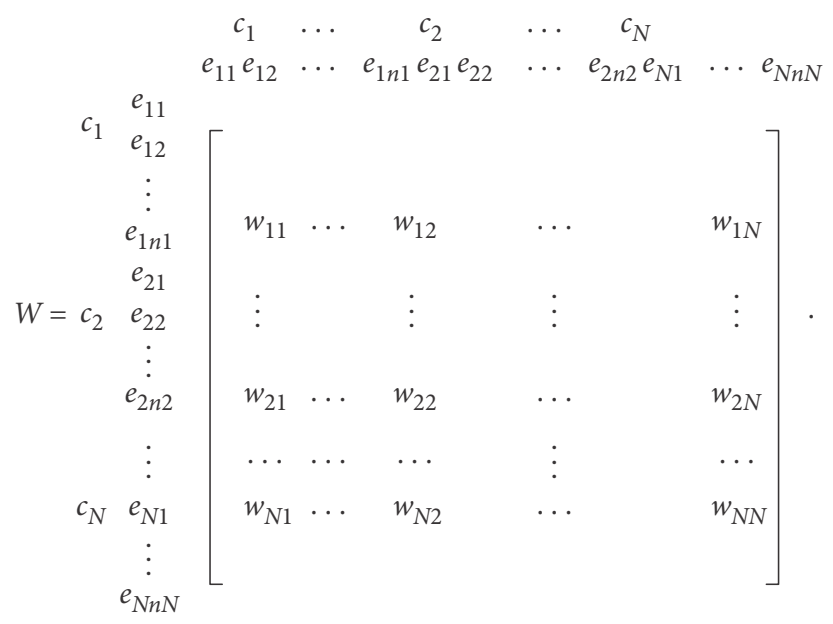

A priority vector derived from pairwise comparison in the usual way represents the impact of a given set of elements in a component on another element in the system. When an element has no influence on another element, its influence priority is assigned as zero (Saaty, 1980). As an example, the matrix representation of a hierarchy with three levels is given by Equation:

$$
W=\left[\begin{array}{ccc}
I & 0 & 0 \\
w_{21} & 0 & 0 \\
0 & w_{32} & I
\end{array}\right],
$$

where $\mathrm{w}_{21}$ is a vector that represents the impact of the goal on the criteria, $w_{32}$ is a vector that represents the impact of the criteria on each of the alternatives, and $I$ is the identity matrix. $W$ is referred to as a super matrix because its entries are matrices. For example, if the criteria are inter-related among themselves, a network replaces the hierarchy. $w_{22}$ would be non-zero and indicates interdependence; this super matrix would be as follows:

$$
W=\left[\begin{array}{ccc}
I & 0 & 0 \\
w_{21} & w_{22} & 0 \\
0 & w_{32} & I
\end{array}\right] .
$$

Now the super matrix has to limit to infinity. The limit is unique, and there is a column vector $\mathrm{W}_{1}$ for which $W^{\infty}=w^{\infty} \times e^{t}$. However, if $W$ is reducible, then the multiplicity $n_{i}$ of the principal eigenvalue has to be considered to obtain the limit priorities of a reducible stochastic matrix with the principal eigenvalue being a multiple root. As an illustration, $n_{i}=1, W^{\infty}$ for a hierarchy with three levels is given as follows:

$$
W^{\infty}=\lim _{k \rightarrow \infty}\left(\begin{array}{ccc}
0 & 0 & 0 \\
w_{22}^{k} w_{21} & w_{22}^{k} & 0 \\
w_{32}\left(\sum_{h=0}^{k-2} w_{22}^{h}\right) & w_{32}\left(\sum_{h=0}^{k-1} w_{22}^{h}\right) & I
\end{array}\right) .
$$


Now, $\left|w_{22}\right|<1$ implies that $\left(w_{22}\right)^{k}$ tends to zero as $k$ tends to infinity, and we have:

$$
W^{\infty}=\lim _{k \rightarrow \infty}\left(\begin{array}{ccc}
0 & 0 & 0 \\
0 & 0 & 0 \\
w_{32}\left(I-w_{22}\right)^{-1} w_{21} & w_{32}\left(I-w_{22}\right)^{-1} & I
\end{array}\right) .
$$

Thus, the impact of the goal on the ranking of the alternatives is given by the $(3,1)$ entry of $W^{\infty}$. 